\title{
The Impact of Financial Liberalization on the Stability of the Financial System in Emerging Markets
}

\author{
Dr. Fouzi Abderzag (Professor) \\ Department of Economic Sciences, Ferhat Abbas University, Setif 01, Algeria \\ Abderzagf@yahoo.fr \\ Balbal Hasnaoui (PhD Student) \\ Department of Economic Sciences, Ferhat Abbas University, Setif 01, Algeria \\ sofianebelbel88@gmail.com
}

Doi:10.5901/mjss.2015.v6n6p22

\section{Abstract}

\begin{abstract}
Many of the reforms appeared and have touched the economic and financial sector, perhaps the most important is the financial liberalization policy that have emerged since the seventies, which aims to ease the degree of restrictions on the financial system in order to enhance the level of efficiency and reform entirely, by opening the financial and capital markets to foreign companies in the fields of banks and insurance and securities and investment firms and fund management and a large number of services. However, the financial liberalization hasty process and random may lead to violent crises and imbalances significant at the level of macro and micro economic, especially those relating to the stability of the financial system in emerging markets, and has become maintain the stability of the financial system at the local and international levels critical for countries in general a target, and the newly industrialized countries in the ways of growth in particular, and the aim of this study is to provide a conceptual theoretical framework of financial liberalization; identify the nature of the financial system and financial stability of emerging markets; and emphasize the importance of a balanced financial liberalization in maintaining the stability of the financial system in emerging financial markets.
\end{abstract}

Keywords: financial liberalization, financial stability, financial crisis and emerging markets.

\section{Introduction}

\subsection{Research background}

Recently the global economy is quickly shifts and changes at the macro and micro levels, the financial and banking sector is the most sensitive sector and in response to these changes, especially in the last quarter of the last century, this is what led to the emergence and the birth of a new financial system, characterized by free movement of capital and removes all regulatory and legislative barriers to expansion and multiple domains, this system is known financial liberalization.

Decision-makers seeking today to find as a quick solution to the repeated crises that hit the capitalist system, which was most recently the 2008 crisis, and that in order to maintain the stability of the financial system in the financial markets in general and emerging markets in particular, what has made this stability is also a strategic goal for many international financial institutions, especially the International Monetary Fund and the World Bank, which have become dailies many reports and studies rotating in order to achieve stability in the financial system and keep it, and the financial system consists of many of the link elements close with each other, and that any disturbance occurs in a component of the These elements lead to a weakening of the stability of the entire financial system.

\subsection{Problem statement}

The financial liberalization has many advantages and positive aims, but it remains one of the largest causes of crises that touched the economics of many developed and developing countries, the policy of financial liberalization immediate and non-caution, especially in economies fragile inevitably lead to violent crises, it may be difficult to get out of them, so to be on the countries that want to adopt this policy to work hard in order to improve the financial and economic sector before 
entering into liberalized phase, and the problem we are trying to answer them is through this following questions:

- What is the definition of financial liberalization?

- How financial liberalization contributes to the stability of the financial system in emerging markets?

\subsection{Research objectives}

The purpose of this study is to explore the relationship between financial liberalization and stability of the financial system in emerging markets, and specifically we seek:

- Provide theoretical and conceptual framework of financial liberalization;

- Identify the risks and criticism of financial liberalization;

- Explore the relationship between financial liberalization and stability of the financial system in emerging financial markets;

- Identify the requirements and conditions of the success of the financial liberalization policy in emerging financial markets.

\section{The Financial Liberalization}

\subsection{Definition of Financial Liberalization}

The concept of financial liberalization appeared with the end of the sixties in the developed countries, followed by a later developing countries through a set of measures aimed at reforming the financial sector, which is considered among the most prominent global economic reform policies.

- According to Kaminsky \& Schmukler (2003), the financial liberalization consists of the deregulation of the foreign sector capital account, the local financial sector, and the stock market sector viewed separately from the local financial sector ${ }^{1}$.

- Financial liberalization is the process of breaking away from a state of financial repression. As financial repression has been most commonly associated with government fixing of interest rates and its adverse consequences on the financial sector as well as on the economy, financial liberalization, in turn, has come to be most commonly associated with freeing of interest rates?

- Financial liberalization is defined as a process of dismantling all forms of quantitative or qualitative regulatory control restrictive state-imposed on institutional structures, instruments and activities of various agents on segments of the financial sector, not only in internally but also internationally ${ }^{3}$.

Through the previous we can say that the financial liberalization is the set of procedures that are working on the development of financial markets, which are taken by the State to eliminate or mitigate the degree of restrictions on the financial system, and this in order to enhance the level of efficiency and reform entirely, by opening the financial and capital markets to foreign companies.

Table 1: Official date of financial liberalization

\begin{tabular}{|l|c|}
\hline Country & Official financial Liberalization \\
\hline Algeria & $/$ \\
\hline Argentina & 1989 \\
\hline Brasil & 1991 \\
\hline Chile & 1992 \\
\hline Morocco & 1997 \\
\hline Egypt & 1992 \\
\hline India & 1992 \\
\hline Indonesia & 1989 \\
\hline Jordan & 1995 \\
\hline Corea & 1992 \\
\hline Malaysia & 1988 \\
\hline Mexico & 1989 \\
\hline Pakistan & 1991 \\
\hline Philippines & 1991 \\
\hline
\end{tabular}




\begin{tabular}{|l|c|}
\hline Peru & 1993 \\
\hline Thailland & 1987 \\
\hline Tunisia & 1994 \\
\hline Turkey & 1989 \\
\hline Uruguay & $/$ \\
\hline
\end{tabular}

Source: Amaira Bouzid(2006), Les conditions préalables à la réussite des réformes financières au sein des pays émergents, 23èmes Journées d'Economie Monétaire et Bancaire, Jeudi 22 et vendredi 23 juin, Lille, France.

\subsection{The Negative Effects of Financial Braking}

The Financial braking result several negative effects among it the following4:

- Low nominal interest rates on deposits and lending rates to some extent become his real interest rates in light of the increasing;

- Bad credit oriented supposed to support and guide her to the allocation of sectors;

- Local physical assets become less attractive than other alternatives of foreign assets, and led to a shrinking patch formal financial system as measured by local financial assets to GDP;

- Lack of financial sector diversification, so that characterize the rule of the banking sector and the decline in the relative importance of the securities markets;

- Low degree of financial depth, which refers to the relative size of public liquidity is measured by the gross local product.

\subsection{Benefits and Risks of Financial Liberalization}

Financial liberalization policy has many advantages, also has a lot of challenges and risks 5 :

- In recent decades, there has been a gradual trend toward liberalization of capital flows, both inward and outward, among member countries. The trend has been particularly pronounced in emerging Europe, although systemically important emerging economies (including, for example, China and India) have also announced plans for further liberalization. The pace of liberalization moderated slightly in the wake of the global crisis, but the general trend across the world remains one of increasing openness to cross-border capital flows. Where authorities have intervened to influence capital flows, they have generally done so not by re-regulating permanently significant parts of the capital account but by targeting temporarily specific types of flows.

- It is recognized that CFMs can impose costs on the economy: They can reduce discipline in financial markets and public finances, tighten financing constraints by restricting the availability of foreign capital, and limit residents' options for diversifying their assets. They can also be costly to monitor and enforce, promote rentseeking behavior and corruption, and facilitate repression of the financial sector, impeding financial development and distorting the allocation of capital.

- The move toward liberalization reflects countries' recognition of the benefits of capital flows under the right conditions: At a microeconomic level, capital flows can enhance the efficiency of resource allocation and the competitiveness of the local financial sector. Moreover, as countries develop they require more advanced financial systems, which often go hand in hand with greater cross-border capital flows.16 In addition, capital flows can facilitate the transfer of technology and management practices, particularly through foreign direct investment (FDI). Capital flow liberalization can have indirect or collateralll benefits for intermediate objectives, such as financial sector development, macroeconomic policy discipline, trade, and economic efficiency.

\subsection{Financial liberalization measures}

Requires a set of procedures, which are applied to the internal and external levels:

- Liberalization of the internal financial sector: includes three key variables6:

- Liberalization of interest rates: This is done by reducing the task of identifying high rate ceilings creditor interest and the city, and left control is determined in the market to meet the exhibitors and demand money to invest, and through the convenience between consumption and investment spending.

- Edit Credit: This reduction of credit controls directed towards specific sectors, and as well as the development of higher credit ceilings on loans granted to the rest of the other sectors, and secondly to 
cancel the excessive compulsory reserves for banks, and the liberalization of banking competition to cancel and remove the restrictions and obstacles that hinder the establishment of local and foreign banks.

- Cancel all associated with the competence of the bank restrictions and financial institutions: by giving the opportunity for banks to improve their performance and conduct, especially in light of the intense competition, where they become unable to cope with investor demands, and work to bring the largest number of savers, when controls in interest and commission rates.

- Financial liberalization measures at the external level: include financial liberalization policies at the international level, many of the actions that can be displayed as follows?

- The abolition of exchange controls: relying variable exchange rate is determined in accordance with changes in market forces, as the local currency's exchange rate reflects the real prices of the various levels of local assets.

- The opening of the capital account: This means that the free movement of money in and out of the economy, and specifically to and from the financial markets, and remove the control of the exchange rate that was applied to the transactions associated with the current account and the capital account, and reduce the gap between the nominal and real exchange rate and the liberalization of capital flows.

- Open stock markets: easing restrictions on stock markets and that will work to increase the efficiency of financial markets, through the abolition of barriers or reduced before joining investors and companies to contribute to the market or to withdraw from it, for something that enhances the promotion of joint-stock companies and give them freedom wider in determining how the issuance of securities.

Each one of BEN GAMRA and CLEVENOT(2008) proved in a study they conducted that whatever measures and steps to financial liberalization policy, it can be summarized according to the following equation:

$L F=1 / 3 L S B I+1 / 3 L M F+1 / 3 L C C$

$L F$ : financial liberalization.

LSBI: internal liberalization of the banking system (local).

LMF: liberalization of financial markets.

LCC: liberalization of the capital account.

Based on the degree of liberalization of each side of the previous three aspects mentioned, can be judged on the degree of financial liberalization in the economy as a whole for each country.

Once the initial conditions for the success of financial liberalization are met, the next step is to define the order of adoption of financial reforms and their speed within each emerging economy ${ }^{9}$.

Table 2: The steps of economic and financial liberalization

\begin{tabular}{|c|c|c|}
\hline Sector & Internal & External \\
\hline Real & $\begin{array}{l}\text { Step 1 } \\
\text {-Stabilization } \\
\text {-Liberalization Price } \\
\text {-Levee Implicit and explicit taxes and subsidies } \\
\text {-Privatization }\end{array}$ & $\begin{array}{l}\text { Step } 3 \\
\text {-Liberalization Operations common (removal of } \\
\text { trade barriers) } \\
\text {-Creating a market of exchange and external } \\
\text { currency convertibility }\end{array}$ \\
\hline Financial & $\begin{array}{l}\frac{\text { Step } 2}{\text {-Restructuration and privatization of the local banking system }} \\
\text {-Create or reactivation money market }\end{array}$ & $\begin{array}{l}\frac{\text { Step } 4}{\text {-Levee Control of capital movements }} \\
\text {-Total Convertibility currency }\end{array}$ \\
\hline
\end{tabular}

Source: Amaira Bouzid(2006), Les conditions préalables à la réussite des réformes financières au sein des pays émergents, 23èmes Journées d'Economie Monétaire et Bancaire, Jeudi 22 et vendredi 23 juin, Lille, France.

\section{The Stability of The Financial System and Emerging Markets}

\subsection{The Stability of The Financial System}

It is working to ensure the strength and integrity of the work of all the components of the financial system, which comprises the absence of convulsions and tensions in this device including a negative impact on the economy, which can be understood through the following ${ }^{10}$ :

- The financial stability of all system components; 
- The stability of financial markets and related activities;

- Given a great importance of institutions and commercial banks for its sensitivity and its relation to the historical crises when they occur.

Thus financial stability are closely linked to the financial system and all its components, not just the ability to contain the crisis, and to address various imbalances left behind, Financial Stability expresses the financial system power through what is provided by the protection of depositors and investors, and conservation on payment systems and protection from shocks.

\subsection{The financial stability of the system requirements}

In order to have a stable financial system we have to follow some aspects ${ }^{11}$ :

- The conduct of efficient distribution of economic resources, by geographic regions and with the passage of time, along with other financial operations;

- Assessing financial risk, pricing, identification and management;

- The continued ability to perform basic functions even with exposure to shocks abroad or in the event of accumulation imbalances;

- $\quad$ Provide protection for depositors;

- Support for price stability (monetary policy);

- To encourage the immediate settlement of financial transactions.

\subsection{Determinants of the stability of the financial system}

Can be classified as the determinants of the stability of the financial system under the three groups as follows ${ }^{11}$ :

- Macro-economic conditions: The preservation of the stability of the financial system requires a strengthening of macroeconomic and structural policies appropriate, where credit

- $\quad$ institutions are affected by changes in the macroeconomic environment where they are active.

- The internal device to run the risk of financial institutions and markets: in order to maintain the stability of the financial system must provide the appropriate institutional and regulatory framework, and this is for all levels of framing the nature and risk management in the institutions that compose it.

- The effectiveness of the regulatory and supervisory device for financial institutions and payment systems: The effectiveness and efficiency of the institutional framework and the ability of the system to adapt to innovations financial and environmental changes, are also considered the conditions necessary to maintain the stability of the financial system.

\subsection{The Nature of The Emerging Financial Markets}

Emerging financial markets have largely succeeded in mobilizing savings and attract international investors operation, and it is markets emerged during the past couple of decades as an important pole in the global economy and influencing the structure of international capital flows.

The emerging financial markets does not mean a recent emergence of a market, but we can find among these markets are established long ago (India Stock Exchange in 1875, the Cairo Stock Exchange 1904), is that the label launches on the overall stock market recorded an upswing in the ten-year two years starting from the year $1990^{13}$. And wrongly IFC as shares and credit in the country market is national income (GDP) per person is less than $\$ 10,000^{14}$.

List of emerging financial markets by regional groups could be included in the following table:

Table 3: The Emerging Financial Markets by Regional Groups

\begin{tabular}{|l|l|l|l|l|l|}
\hline Latin America & East Asia & South Asia & Europe & Africa & Middle East \\
\hline Argentina & China & India & Russia & South Africa & Israel \\
Brazil & South Korea & Indonesia & Hungary & Nigeria & Egypt \\
Chile & Philippines & Malaysia & Bologna & Tunisia & \\
Colombia & Taiwan & Pakistan & Czech Republic & & \\
Mexico & Sri Lanka & & Greece & & \\
Peru & Thailand & & & & \\
Venezuela & & & & & \\
\hline
\end{tabular}

Source: International Finance Corporation (www.ifc.org) 


\section{The Requirements of the Financial System Stability in Light of Financial Liberalization for Emerging Markets}

The application of financial liberalization policies in emerging financial markets without clear strategies, these markets may be exposed to many risks and acute crises, and this is through the possibility of foreign investment and capital escape, in addition to the inability to control the stability of the financial system in this market and a significant disruption of this system.

\subsection{Criticism of financial liberalization policy}

Critics of financial liberalization think it increases the risk of attacks by speculative and raise the country's vulnerability to international shocks and capital flight, and according to (Gridlow, 2001), it was taken to developing countries during the years of 1980 and early 1990 to the belief that foreign investment in the form of shares and bonds traded on the local market characterized by the nature of stability in the long term compared to foreign bank loans, which attracted over 1970 years. However, cases of capital flight from emerging markets led in the late 1990s to refute this myth. In another paper noted (Baldacci, De Mello and Inchauste Combini, 2002) increase in financial crisis after the adoption of Mexico editorial policy, and in similar studies reach (Kaminsky and Schmuckler, 2001) and (Tornell and all, 2004) to the financial liberalization process may caused the creation of spikes and collapses deeper into emerging markets, says (Stiglitz and all, 1994) that the asymmetry of information, which is a special feature of financial markets and transactions in developing countries, would be detrimental to the process of editing, consider also that compared to developed counterparts, find markets Emerging themselves unable to compile the relevant financial transactions, information, and therefore cannot flow to the capital, where productivity outweigh the marginal opportunity cost guarantee ${ }^{15}$.

\subsection{The success of financial liberalization policy in emerging financial markets requirements}

For the success of financial liberalization policy in emerging financial markets must be a set of requirements and conditions are available in order to maintain the balance of the financial system ${ }^{16}$ :

- The availability of a stable economic environment: financial liberalization requires a stable climate of the economics of college, until college to take advantage of its benefits, if inflation and large budget deficits and exchange rates is supported by macroeconomic and could have an adverse effect on integration with the international financial system.

- Financial liberalization requires a monetary policy geared towards stability: So it was the financial institutions to support their role in financial intermediation properly it requires a climate of low and stable inflation, since the liberalization of interest rates required before proceeding with the control of inflation. Rising inflation may impose on the Liberation raise nominal interest rates to very high levels to achieve positive real rates, and the best guarantee of that is through monetary policy can predict with being directed towards stability and stability.

- The availability of an efficient financial sector and stable: to deliver the item to be the presence of structural reforms are working to build an efficient and stable financial sector.

- Availability of appropriate institutional and legal structure: preferably before embarking on deregulation and financial openness must provide institutional and legal structure appropriate, since the failure to observe this could lead to serious financial crises, which leads to lower financial depth is supposed to rise in light of financial liberalization levels, where it is necessary to provide a legal structure preserves property rights, the judicial system efficiently separates the fairness of the proceedings and speed, combined with a mechanism for effective implementation of the provisions.

- Regulation and supervision of the appropriate financial institutions: in order to strengthen the stability of the financial sector, it must work well that every financial institution mediating pass the risks need to organize and oversee serious, and that the regulation and supervision of Capricorn important for banks because a financial institution or more failure can lead to a crisis in the whole market as a result of loss of confidence in the banks leading to pull the depositors and borrowers of funds, this in turn could destabilize the overall economics and economic activity.

Through all of the previous it is clear to us that for the success of the policy of financial liberalization in the financial markets in general and in emerging financial markets in particular, has to be a clear and stable fiscal policy of the state, and must provide the following:

- The financial system's ability to cope with the emerging market of violent and sudden shocks, and taking into 
account local and international right conditions for the adoption and the launch of financial liberalization policy;

- The control of the government over inflation, which must be the rate of inflation is very weak for the smooth and flexibility in the financial liberalization process;

- Develop a system for control by which is the supervision of all financial institutions and banks, in order to provide the necessary information in a timely manner to avoid risks and crises;

- The efficiency of the local financial system and its ability to cope with intense competition, in the event that was open in front of the field of investment and foreign private sector in the side of transactions and financial services;

- Gradual liberalization of the financial sector, to avoid the total liberation and timely because of its risk to the local financial system, as well as local financial crises occur with the passage of time has become universal.

\section{Conclusion}

In conclusion, we wish to say that financial liberalization are vital to develop the emerging financial markets and maintain a settled financial system, if they were to take the necessary procedures for the editorial policy and requirements, and if you happened to the contrary, this policy dire consequences on the economies of emerging nations, and among the most important findings of this Study the following:

- Financial liberalization policy is still not clear to many of Theology and international institutions, because of the latter's role in modulating and the principles of a new concept;

- Contributes to financial liberalization is extremely careful in the incidence of violent crises in emerging economies;

- There are many economists who provided researchers barbs financial liberalization and states that adopt these politicians;

- The investment climate in emerging financial markets is not encouraging, given the lack of adequate protection for investors' deposits;

- Follow the gradual liberalization and serial capital contributes significantly to ensure relative stability of emerging markets money;

- Assume the newly industrialized countries in the way of growth is of paramount importance to the process of financial liberalization on the one hand, and wary of the negative consequences of violent than the other hand.

\section{References}

Philip Arestis, Asena Caner (2004), Financial Liberalization and Poverty: Channels of Influence, The Levy Economics Institute, Working Paper $\mathrm{N}^{\circ} 411$.

Murat Ucer, Notes on Financial Liberalization (2000), Proceedings of the Seminar: Macroeconomic Management: New Methods and Current Policy Issues, Held in Turkey, pp01-12.

Saoussen Ben Gamra \& Dominique Plihon (2007), Politiques De Libéralisation Financière Et Crises Bancaires, journal of Économie internationale, $\mathrm{N}^{\circ} 112$, pp5-28.

Mohammed Amine Burberry(2008), Financial Liberalization And Banking As A Mechanism To Increase The Competitiveness of Commercial Banks In Algeria, Intervention within the Second International Scientific Conference: Reform of the Algerian banking system in light of current developments, 11 - 12 March, Kasdi Merbah University, Ouargla, Algeria.

Olivier Blanchard and all (2012), The Liberalization And Management of Capital Flows: An Institutional View, International Monetary Fund, November 14, pp01-48, Available: http://www.imf.org/external/np/pp/eng/2012/111412.pdf (March 22, 2015).

Abdul Hamid Bokhari, Ali Boussaha(2011), Financial Liberalization and Efficiency of The Banking Performance In Algeria, The Intervention Introduction Within The Second International Seminar: The Outstanding Performance of Organizations and Governments, Second Edition: The Growth of Institutions and Economies Between Achieving Financial Performance And Environmental Performance Challenges, November 22 - 23, Kasdi Merbah University, Ouargla, Algeria. pp133-152.

Abdul Ghani Hariri (2009), The Role of Financial Liberalization in Crisis and Faltering Banking, Research and Working Papers International Seminar: The International Financial and Economic Crisis and Global Governance, Publications Laboratory Partnership in The SME of The Euro-Maghreb Space, Dar Al-Huda for printing, publishing and distribution, Ain Melilla, pp201218.

Saoussen Ben Gamra, Michael Clévenot (2008), Financial Liberalization in Developing Countries, Economic Growth and Financial Instability, Paris XIII University, Version $N^{\circ} 1$ to September 20.

Amaira Bouzid(2006), Les conditions préalables à la réussite des réformes financières au sein des pays émergents, 23èmes Journées d'Economie Monétaire et Bancaire, Jeudi 22 et vendredi 23 juin, Lille, France.

Ahmed Mahdi Bloafi(2008), Islamic Banks and Financial Stability: An Empirical Analysis - discuss the results of a working paper issued 
by the International Monetary Fund, Journal of King Abdul Aziz University: Islamic Economics, Vol. 21, №. 02, pp71-96.

Rima Dahbi(2012/2013), The Formal Financial Stability: Building A Synthesis of The Algerian Financial System Indicator: For The Period 2003-2011, The Thesis Submitted for Certification LMD Phd in Economic Sciences, Department of Economic Sciences, University of Constantine 02, Algeria. Ibid, pp 22-23.

Hassan Khabbaba(2004), The Role of Stock Markets in The Arab Countries in Economic Development, Journal of Human Sciences, Mohamed Khider, Biskra University.

Saad Merabet, Asmaa Belmihoub(2006), Financial Globalization and its Impact on The Performance of The Emerging Financial Markets, Intervention Within The International Seminar: Funding Policies And Their Impact on The Economies And Institutions, Algeria's Case Study and Developing Countries, November 21-22, Mohamed Khider University, Biskra, Algeria.

Mohamed Zakaria Ben Maazou, Kamal Hamaneh(2013), Measuring The Relationship Between Financial Liberalization And Economic Growth in Algeria Using Index (KAOPEN) - Empirical Study (1970-2010), Journal of the researcher, № 13, pp 19-30.

Abdul Ghani Hariri, Radwan Onsaad(2008), Management Strategy of The Risk of Financial Liberalization in The Arab Countries, Intervention in The Third International Seminar: Risk Management Strategy in Institutions - Reality And Prospects, 25 - 26 November, Hassiba Ben Bu Ali University, Chlef, Algeria. 